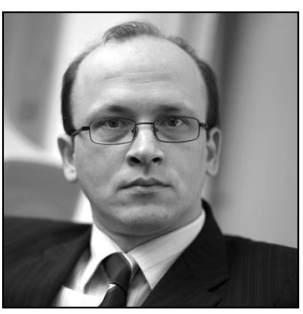

Andres Vutt

Associate Professor of Commercial Law University of Tartu

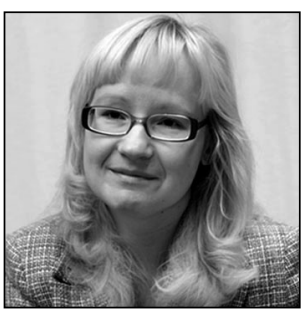

Margit Vutt

Judge, Tartu County Court PhD, Lecturer of Civil Law, University of Tartu

\title{
Shareholder Exit in Estonian Private Limited Companies: Proposals of the Company Law Revision Working Group
}

\section{Introduction}

Because of its attractiveness, the private limited company is a widely used company form both in Estonia and in other European countries. ${ }^{{ }_{1}}$ Yet, the private limited company, being a closed company, has always been and always will be prone to conflicts between the majority and the minority shareholders. ${ }^{*}$

Although many possible future shareholder conflicts could be alleviated by designing appropriate rules for resolving future disagreements into the articles of association or a shareholder agreement already when one is establishing a company, this may be difficult in practice. Failure to conclude a comprehensive statute or shareholders' agreement, one that foresees all possible future problems, can be explained, on the one hand, by the bounded rationality of shareholders, which underestimates future risks and, on the other hand, by the fact that the costs of producing complex contract documents may be too high for a small company. ${ }^{*}$ It must be noted also that, at the stage of setting up a company, future conflicts often are not foreseen or get overlooked. Furthermore, business relations are frequently intertwined with other types of close relationships (i.e. business partners are often also family members or good friends) that cannot be fully regulated by law. If the personal relations deteriorate, however, it is already too late for the shareholders themselves to regulate the problems.

Types of conflicts may vary, depending on whether the private limited company has a majority shareholder, the votes are divided equally between two shareholders, or there are voting blocs. The problems of a private limited company in a deadlock are undoubtedly more severe, since in this situation even the

1 According to German legal literature, there are more than a million private limited companies in Germany (there, GmbH entities); see F Wedemann, Gesellschafterkonflikte in geschlossenen Kapitalgesellschaften (Beiträge zum ausländischen und internationalen Privatrecht 99, Mohr Siebeck 2013) 1. - DOI: https://doi.org/10.1628/978-3-16-152541-4. The same is true for Estonia: in 2018, the country had nearly 200,000 private limited companies. See J Järve, 'Eesti ühingute statistiline ülevaade' ['Statistical Overview of Estonian Companies'] (2019) 6 <https://centar.ee/wp-content/uploads/2019/08/2019 .06.13-Eesti-\%C3\%BChingute-statistiline-\%C3\%BClevaade-l\%C3\%B5plik-1.pdf > accessed 2 July 2021.

2 German legal literature has expressed the view also that, especially in small companies, conflicts between shareholders are easily encountered. See Wedemann (n 1) 1.

3 Wedemann (n 1) 61-80. 
day-to-day management of the company may become hampered, while the problem in a private limited company with a majority shareholder tends to be that the majority abuses its rights and the minority responds, in turn, with obstruction, which is manifested mainly in various kinds of legal disputes that exhaust the company. Even if the court solves one legal dispute, it does not essentially resolve the conflict between the shareholders, since the only real solution for the arguing shareholders would be to not continue together in the same company. One can assume, therefore, that a private limited company needs proper exit rules that would not only benefit the shareholders but also protect the company.

In 2016, the Estonian Ministry of Justice launched the project for the Estonian Company Law Review. ${ }^{* 4}$ Among other issues, the aim of the project was to analyse that of the legal remedies available for minority shareholders to deal with the various types of conflict situation and the compatibility of existing remedies with the needs of practice and to propose, if necessary, amendments to existing law. In 2018, the working group of company-law experts ${ }^{*} 5$ presented its proposals for amendment of the law. ${ }^{* 6}$

This article examines shareholder exit in a private limited company in current Estonian law in comparison with similar regulations of some other European countries. The comparison is based on German, Swiss, Belgian and Dutch law. These countries were selected for analysis by the working group too, on the grounds that Belgium and the Netherlands already have comprehensive regulation in place in this field, while the system of claims specific to Estonian private law, as well as Estonian civil procedural law, are based largely on German and Swiss law. The aim for the article is to give an overview of current Estonian law and the proposals put forth for resolving conflicts between shareholders by the working group of Estonian company law experts.

\section{Current Estonian law}

At present, Estonian company law has no general rules regulating a private limited company's shareholder exit. Estonian Commercial Code $^{*}$ regulates only the exclusion of a shareholder in case he or she has materially breached his or her obligations. According to Section 167 (1) of the CC, a court may exclude a shareholder from a private limited company on an action brought by a private limited company if the shareholder has failed to perform his or her obligation to a significant extent without good reason or has otherwise significantly damaged the interests of the company and, despite a written warning from the company, has neither performed the obligation nor terminated the damage. Paragraph 167(2) of the CC provides that an action for the exclusion of a shareholder may be brought on behalf of a private limited company by shareholders whose shares represent more than half of the share capital, unless the articles of association require greater representation. According to Section 167(3) of the CC, if the shareholder is excluded, his or her share shall be sold by public auction or by other means determined by the court.

There are several problems related to the above-mentioned provisions. For example, there is lack of clarity with regard to what it means to 'bring an action on behalf of a private limited company'. It is also unclear whether the shareholders are special representatives of the company or does it merely mean that, before applying to the court, the shareholders must adopt a corresponding resolution. It has been noted in the legal literature that, on account of the mandatory nature of the regulations, it is probably not possible to stipulate an exclusion procedure different from this in the articles of association of the company. ${ }^{*}$ Likewise, the procedure of selling the share provided for in paragraph 3 is neither effective nor a means of granting the excluded shareholder a fair price for his or her share.

The exclusion of a shareholder has not featured very often in Estonian case law. The Supreme Court has stated in only one of its decisions that if a minority shareholder significantly harms the interests of a private

4 Ministry of Justice of Estonia, 'Ühinguõiguse kodifitseerimise lähteülesanne' ['Terms of Reference of the Company-Law Review'] (2016) <www.just.ee/sites/www.just.ee/files/uhinguoiguse_revisjoni_lahteulesanne_loplik_10.5.2016.pdf> accessed on 2 July 2021.

5 The authors of this article, alongside other Estonian legal scholars, were members of the above-mentioned working group.

6 Ministry of Justice of Estonia, 'Ühinguõiguse revisjoni analüüs-kontseptsioon' ['Analysis Concept for the Company-Law Review'] (2018) <www.just.ee/sites/www.just.ee/files/uhinguoiguse_revisjoni_analuus-kontseptsioon.pdf> accessed on 2 July 2021.

7 Commercial Code (äriseadustik). RT I, 04.01.2021, 46 (CC).

8 K Saare and others, Ühinguõigus I. Kapitaliühingud ['Company Law I: Limited Companies'] (Juura 2015), marginal note 1197. 
limited company (e.g. if he or she tries to block the activities of the company), the majority shareholders may require his or her exclusion from the company. ${ }^{*}{ }^{*}$

Furthermore, there are currently no rules in Estonian law governing the right of a minority shareholder to demand exit from the company even when there are long-standing fundamental disagreements between shareholders. In such a situation, the only remedy would be, in essence, to bring these disagreements to an end via dissolution of the company, but if the shareholders do not adopt the respective decision, the disagreement may result in compulsory dissolution or even bankruptcy, which is a good solution for neither the shareholders nor the creditors. When a minority shareholder wishes to exit a private limited company, his or her only option is to sell the share. However, shares of a private limited company are, as a rule, not freely transferable. ${ }^{* 10}$ Therefore, the only one who might be interested in buying a minority share could be the majority shareholder, who is usually not interested in acquiring such a minority shareholding - after all, he or she already controls the company. Even if the majority shareholder does wish to buy out the minority, there is no reason to offer the minority a fair price for his or her share.

The Estonian legal literature has raised the question, however, of whether a shareholder's exit right could be derived from the fact that, fundamentally, the relations between shareholders are very similar to those between the parties to a long-term contract.

According to Section 196(1) of the Law of Obligations Act, ${ }^{* 11}$ each party in a long-term agreement may extraordinarily terminate the contract with good reason without giving advance notice, particularly if the party terminating the contract cannot reasonably be expected to continue performing the contract until the due date agreed upon when all the circumstances and the mutual interests of the parties have been taken into account. Paragraph 196(2) of the LOA provides that if the other party breaches his or her contractual obligation, the contract may be terminated only after the expiry of a reasonable period granted to the party having failed to fulfil his or her obligation and only if he or she does not remedy the breach within that period. The setting of an additional time limit is not necessary only if the breach is fundamental. ${ }^{* 12}$ According to Section 1(1) of the LOA, the general provisions of the LOA apply to all contracts and other multilateral transactions, as well as to contracts that, although not specified by law, are not contrary to the content and meaning of the law and to non-contractual relations. Hence, if the relationships that arise between the shareholders are to be regarded as a contract, Section 196 of the LOA, as a basis for extraordinary termination, should apply to the relations between a company's shareholders too. ${ }^{* 13}$ It is argued, therefore, that terminating the 'participation' in the company should be possible also. ${ }^{.14}$

In addition to the general provisions, this act regulates the partnership agreement. ${ }^{*}{ }^{15}$ Therefore, one can ask whether the provisions of LOA regulating partnership agreement (at least the general regulations) could be applied to the relations of the shareholders of a private limited company. Namely, Section 597(1) of LOA provides that a partner has the right, at any time, to terminate a contract of partnership established for an unspecified term. In contrast, a contract of partnership that is entered into for a specified term may be terminated only with good reason. The primary reason in this regard shall be a material violation of an obligation by another partner. The above-mentioned right of termination is balanced by Section 597(4) of the LOA, which provides that the partnership agreement may not be terminated at a time when the dissolution of the partnership would unreasonably damage the lawful interests of the other partners. If a partner terminates a contract of partnership at such a time without good reason, the terminating party is required to compensate for any damage incurred by the other partners for this reason. ${ }^{* 16}$

9 Supreme Court Civil Chamber Decision 3-2-1-197-11, para 35.

10 According to ss 149(1) and (2) of the CC, a shareholder may freely transfer a share to another shareholder. Upon transfer of a share to a third person, the other shareholders have a pre-emptive right to acquire the share.

11 Law of Obligations Act (Võlaõigusseadus). RT I, 04.01.2021, 19 (LOA).

12 Fundamental breach is defined in s 116 (2) of the LOA. One of the conditions is that the breach is fundamental if the nonperformance of an obligation was intentional or due to gross negligence or if the non-performance of an obligation gives the injured party reasonable cause to believe that the injured party cannot rely on the other party's future performance.

13 U Volens and M Moor, 'Kas osanikul on õigus osaühingust välja astuda ja nõuda oma osa eest ühingult hüvitist?' ['Is the Shareholder Entitled To Withdraw from the Private Limited Company and Claim Compensation from the Company for His Share?'] (2012) X Juridica 765.

14 Ibid 764-66.

15 LOA, paras 596-618.

16 U Volens and M Moor (n 13) 766. 
The approach described above may be theoretically correct, but Estonian case law has not confirmed the exit right of a shareholder of a private limited company. This is probably at least partly caused by the fact that a general principle of company law stipulates that, when resolving disagreements between shareholders, one must take into account not only the interests of the arguing parties but also the interests of the company and all its interest groups. ${ }^{* 17}$ Likewise, the above-mentioned general rules of the law of obligations are still to be applied only selectively. For example, in the event of extraordinary termination of an agreement, the usual rules on return of what was delivered under the contracts and on compensation therefore would not apply. ${ }^{*} 18$ Furthermore, rules on how to calculate the compensation to be paid to a leaving shareholder should be borrowed from somewhere else using the analogy of law.

It has been noted also that the legal relations between shareholders are similar to co-ownership, which likewise can be terminated (normally with no special reason needed). ${ }^{* 19}$ According to Section 76 (1) of Estonia's Law of Property Act ${ }^{* 20}$, a co-owner has the right to demand the termination of co-ownership at any time Although an agreement between the co-owners may exclude the right to terminate the co-ownership, termination can nevertheless be required if there is a substantial reason for it. Unlike in the case of extraordinary termination of a contract, the co-owner has a right to demand termination of the co-ownership only by the courts. These regulations are not applicable for a private limited company, though, and assets of the company as a legal person cannot be considered the property of the shareholders and therefore cannot be divided among them.

One can ask as well whether it is possible for a shareholder who wants to leave a private limited company to force the other shareholders to vote for a resolution that allows him or her to exit. Estonian private law represents the concept that a shareholders' decision is a special type of multilateral transaction, according to Section 67(2) of the General Part of the Civil Code Act ${ }^{* 21}$, or GPCCA, and a vote cast in a shareholder meeting is a declaration of intention according to its Section 33(1). Section 68(5) provides that if a person is obliged to make a declaration of intention with certain content, the declaration of intention can be replaced with a court decision obliging that person to make such a declaration of intention. The claim to oblige a person to make a certain declaration of intention is meant to be a special legal remedy in case a person is obliged to make a declaration of intention but does not fulfil the obligation to do so. ${ }^{* 2}$

In the legal literature it has been pointed out that, in order to apply Section 68(5) of the GPCCA, three preconditions must be met. First, a shareholder must be obliged to vote in a certain way pursuant to law, the articles of association of the company, or the shareholders' agreement, and, secondly, the content of the decision to be made must be unambiguously identifiable. Finally, the court decision has to oblige the refusing shareholder to vote for the decision. ${ }^{*} 3$ It has been argued that it is possible that, in certain circumstances, a shareholder may have an obligation to vote in favour of a particular decision on the basis of the general principle of good faith. ${ }^{* 2}$ This view is expressed in Estonian case law also, as the Supreme Court has stated that the content of the shareholder relationship and the obligations arising therefrom are determined, in particular, by Section 32 of the GPCCA, which is why shareholders must respect the principle of good faith in their relations and take into account each other's legitimate interests. ${ }^{* 25}$ However, legal

17 This principle has been pointed out also in Estonian case law (e.g. Supreme Court Civil Chamber Decision 3-2-1-89-14, para 36).

18 According to s 189 (1) and s 196 (4) of the LOA, in the event of termination of a contract, each party may claim for return of that which it delivered under the contract and delivery of the fruits and other gains received if said party returns all property that has been delivered to it.

19 U Volens and M Moor (n 13) 765.

20 Law of Property Act (Asjaõigusseadus). RT I, 22.02.2019, 11.

21 General Part of the Civil Code Act (Tsiviilseadustiku üldosa seadus). RT I, 23.05.2020, 4 (GPCCA).

22 It has been noted in the legal literature that if a person fails to comply with the obligation to make a certain declaration of intention, it may be possible to exercise other remedies, particularly to make a claim for compensation of damages or to demand a contractual penalty provided for in the contract, but without s 68(5) of the GPCCA the enforcement of the obligation would not be possible; see P Varul and others, Tsiviilseadustiku üldosa seadus. Kommenteeritud väljaanne (Juura 2010), Saare, s 68 Comm 3.5.1).

23 M Vutt, 'Osaniku ja aktsionäri hääletamiskohustus kui hääle kohtulahendiga asendamise eeldus' ['The Voting Obligation of a Shareholder as a Prerequisite for the Replacement of the Vote by a Court Decision'] (2017) VI Juridica 394.

24 According to 32 of the GPCCA, the shareholders of a company shall act in accordance with the principle of good faith and consider each other's legitimate interests in their mutual relations.

25 Supreme Court Civil Chamber Decision 3-2-1-89-14, para 21; 3-2-1-65-08, para 26; 3-2-1-7-10, para 31. 
scholars $^{* 26}$ and case law ${ }^{* 27}$ too have pointed out that the obligation to vote is aimed primarily at safeguarding the interests of the company and that if the interests of the shareholders are incompatible with these, preference should be given to the general interest of the company.

It can be inferred from the foregoing that, although it is (at least) theoretically possible for a shareholder to obtain the necessary decision that allows him or her to withdraw by forcing other shareholders to vote in favour of said decision, such an exit option is nevertheless uncertain and, most importantly, costly and timeconsuming. It is likely that the litigation will use up so much time and money that, by the time the court issues a decision that is favourable for the leaving shareholder, his or her share will no longer have any value.

The authors of this article are of the opinion that, at present, there are no clear rules in Estonian law that would allow a shareholder an exit from the company and that the only possible exit is through a share transfer, which may not be possible - or, even if possible, may occur under conditions that are extremely harmful to the shareholder. ${ }^{* 28}$ The case law attests to many legal disputes between shareholders, with most of them derived from broader conflict between the majority and the minority. ${ }^{* 2}$ Therefore, Estonian company law would benefit from legal regulation of shareholder exit. The authors find that the exit rules should be clear and foreseeable for the shareholders and should not be governed by case-law. Legal clarity would be ensured if the law were to define, at least in general terms, the reasons for which a shareholder may withdraw or be excluded, and the law should provide for a procedure for determining (and disbursing) compensation in a way that considers the interests of the company and its interest groups.

\section{The private limited company shareholder's exit right in other countries}

\subsection{Germany}

To choose appropriate examples when developing relevant legal provisions, the company-law revision working group began by analysing the law of Germany and of Switzerland, which have a legal system similar to Estonia's. ${ }^{*} 30$

German company law is similar to its Estonian counterpart in containing no rules governing the exit rights of a shareholder of a limited liability company. ${ }^{*} 31$ It has been noted that if a shareholder wants to leave the company, he or she can only sell the share, either to third parties or to the company, or let the company acquire the share in accordance with Section 34(1) of the $\mathrm{GmbHG}^{*}{ }^{32}$ and the articles of association of

26 M Vutt (n 23) 396.

27 For example, in its decision 3-2-1-89-14, para 36, the Supreme Court pointed out that the voting obligation is aimed in particular at ensuring the interests of the company and preventing it from losing its ability to act for reason of disagreements between shareholders.

28 The possibility of exit is currently regulated only with regard to special situations such as merger, division, and transformation. Art 404(1) of the CC stipulates that upon merger of companies of different classes, a shareholder of the company being acquired who opposes the merger resolution may, within two months after entry of the merger on the registry card of the acquiring company, demand that the acquiring company acquire the exchanged share or shares of the partner or shareholder against monetary compensation. Para 448(1) of the CC foresees the same rules for division and s 488(1) for transformation. The monetary compensation shall be equal to the sum of money that the shareholder would have received from the distribution of remaining assets upon liquidation of the company if the company had been liquidated at the time the merger, division, or transformation resolution was adopted.

29 For example, in 2017-19, the Supreme Court settled, in total, seven disputes between majority and minority shareholders of the same private limited company. See Supreme Court Civil Chamber Decision 2-16-18531, 2-16-3492, 2-16-15457, 2-16-11216 (twice), 2-16-9415, and 2-17-16390. In cases involving a typical shareholder conflict, there are several simultaneous litigation procedures, which include contesting shareholder resolutions, demanding information, and claiming compensation of damages.

30 The Estonian Supreme Court has expressed the view that similar laws and practices in other countries can be considered, at least in private law, as reference material for determining the meaning and purpose of Estonian law. The above applies primarily in situations wherein there is no practice of implementing a provision in Estonia while elsewhere practice has developed in the case of a similar provision. The Supreme Court noted that this consideration pertains primarily to countries with which Estonia has a broadly similar legal system and generally similar practice in the implementation of laws (see Supreme Court Civil Chamber Decision 3-2-1-145-04, para 39).

31 Gesellschaft mit beschränkter Haftung $(\mathrm{GmbH})$.

32 Gesetz betreffend die Gesellschaften mit beschränkter Haftung in der im Bundesgesetzblatt Teil III, Gliederungsnummer 4123-1, veröffentlichten bereinigten Fassung, das zuletzt durch Artikel 16 des Gesetzes vom 22. Dezember 2020 (BGBl. IS 3256) geändert worden ist. 
the company. ${ }^{*} 3$ Paragraph 61 of the GmbHG provides, additionally, that the company may be dissolved via a court ruling if the achievement of the corporate purpose becomes impossible or if there are other important reasons for dissolution rooted in the circumstances of the company. According to the legal literature, Section 61 is intended to compensate for the fact that a shareholder has no statutory right of withdrawal for good reason. The articles of association often do not provide for a right of withdrawal or exclusion of shareholders. The corporate documents often attach special requirements to the transferability of shares, which is otherwise free by law. Here, the right to apply for dissolution of the company is not, however, a right of every individual shareholder but merely a minority right, one that can be executed only by shareholders who own at least $10 \%$ of the share capital. ${ }^{*} 34$

Nevertheless, German case law has affirmed the exit right of a shareholder based on the shareholder loyalty obligation, the basic principles for the protection of minority shareholders, and the extraordinary termination right of a party to a long-term legal relationship. ${ }^{*} 35$ In German legal literature, the right of exit for good reason is considered to be an inalienable right of a shareholder, a right that cannot be excluded or restricted but only extended or specified in the articles of association. ${ }^{*}{ }^{6}$ This right can be exercised if there is a valid reason, if less onerous measures cannot be taken for the same end, and provided that the company retains its equity capital. ${ }^{*} 7$ Valid reasons consist of circumstances that make it unreasonable for the shareholder to remain in the company. ${ }^{*} 38$ The prerequisites for withdrawal are that the shareholder has fully paid his or her contribution to the share capital and that the compensation paid to the shareholder does not violate the principle of the equity capital's preservation. Otherwise, the shareholder cannot exit the company, but he or she can apply for its dissolution under Section 61(1) of the GmbHG.

Under German law, shareholders of companies in deadlock may also exercise the right of exit. Among the other valid reasons are significant changes in the legal and economic conditions of the company, a situation in which a private limited company is transformed into a subsidiary of a group of companies, and long-term oppression by majority shareholders. ${ }^{*} 39$ Not all disagreements between shareholders can be considered serious enough to justify exit, however. For example, it is not sufficient if the shareholder is, for some legal or factual reasons, unable to sell the share or if he or she just urgently needs money. ${ }^{*} 40$ Neither does mere persistent unprofitability of the company justify withdrawal, since this circumstance affects all shareholders in the same way. The same is true of a situation wherein the company lacks correct accounting. ${ }^{*}$ At the same time, the legal literature states that this category of remedies still is extremely rarely used and that most corporate conflicts in Germany are, for some reason, still being resolved through challenging of decisions. ${ }^{*}{ }^{2}$

One can conclude that there are no rules on the withdrawal and exclusion of shareholders in Germany, while the country's case law still recognises this right. Furthermore, a shareholder who owns at least 10\% of the share capital is able, as a last resort, to demand the dissolution of the company through the courts. ${ }^{*} 3$ One of the reasons for which shareholder exit rules have not been introduced into German law is that these rules often are found in the articles of association of German companies. ${ }^{*} 4$

33 A Heidinger, S Leible and J Schmidt (eds), Kommentar zum Gesetz betreffend die Gesellschaften mit beschränkter Haftung (GmbH-Gesetz) (3rd edn, C.H. Beck 2017) s 34, Sosnitza, marginal note 43.

34 H Fleischer and W Goette, Münchener Kommentar zum GmbHG (2nd edn, C.H. Beck 2016), Limpert, s 61, marginal note 1.

35 H Wicke, Beck'sche Kompakt-Kommentare. Gesetz betreffend die Gesellschaften mit beschränkter Haftung (4th edn, C.H. Beck 2020), Anh, s 34: 'Austritt und Ausschließung eines Gesellschafters', marginal notes 10-13.

36 BeckOK GmbHG/Schindler (46th edn 2020) s 34: 'GmbHG’, marginal note 163.

37 Ibid s 34, marginal notes 171-75.

38 The German Federal Supreme Court has made several decisions on this matter, e.g. BGH, Urteil vom 1.4.1953 - II ZR 235/52. BGHZ 9, 157 [162]. - NJW 1953, 780; Urteil vom 16.12.1991 - II ZR 58/91. BGHZ 116, 359 [369]. - NJW 1992, 89.

39 Heidinger and others (n 33) s 34, Sosnitza, marginal notes 52-54.

40 Ibid s 34, Sosnitza, marginal note 52.

41 Ibid s 34, Sosnitza, marginal note 54.

42 Wedemann (n 1) 564.

43 Estonian company law does not include the shareholder's right to apply for the dissolution of the company. Such a remedy is foreseen only for partnerships (per s 105(1) and 126 of the CC).

44 According to the German legal literature, in 2011 such rules existed in the articles of associations of $67 \%$ of companies with several shareholders. See Wedemann (n 1) 473. 


\subsection{Switzerland}

In Switzerland, unlike in Germany, the shareholder's right to withdraw from the company is regulated to some extent. Paragraphs 822(1) and (2) of the Swiss Civil Code (Obligationenrecht), or OR ${ }^{*} 45$, provide that a shareholder may, for a good reason, apply to the courts for permission to withdraw from the company. The articles of association may grant a shareholder the right to withdraw and make this subject to certain conditions. According to Section 821(3) of the OR, a shareholder also has a right to apply to the courts to request the dissolution of the company when there is good cause. Instead of dissolution, the court may opt for an alternative solution that is appropriate and reasonable for the persons concerned, such as the payment of a financial settlement to the shareholder requesting dissolution, commensurate with the fair value of his capital contribution. The above-mentioned paragraphs of the OR also foresee the company's right to apply to the courts for the exclusion of a shareholder when there is a valid reason for this. In addition, the articles of association may provide that the shareholders may decide on the exclusion of a shareholder themselves.

According to the legal literature, Swiss law has significantly extended the judge's right to settle a case of this nature. In practice, however, this right has not been exercised extensively by the courts; i.e. the judges still tend to be conservative. ${ }^{*} 46$

\subsection{Belgium}

For another point of view on the legal regulation of shareholder exit, the working group also examined Belgian law.

In Belgian company law (regulated in Wetboek van vennootschappen, or WV) ${ }^{*} 4$, the exit rights of a shareholder of a private limited company are regulated in articles 636-641.

The fundamental principle for shareholders' exit is that it is an ultima ratio remedy; it can only be used if other measures fail to solve the problem. The procedure is swift, with the aim being to resolve the conflict as soon as possible (it is a summary proceeding). The court has the power to decide whether there is a 'valid reason' for implementing such a measure. The rules governing the right of exit are mandatory, and shareholders cannot deviate from those rules by specifying otherwise in the articles of association.

According to Article 636 of the WV, one or more shareholders owning shares that, in total, have a nominal value or par value of $30 \%$ of the capital of the company may, for legitimate reasons, claim in court for another shareholder to transfer his or her shares to the plaintiff(s). After the summons has been served, the defendant may not dispose of his or her shares except with the consent of the court or the parties to the dispute. Except with regard to the right to dividends, the court may order that the rights attached to the shares to be transferred be suspended. There is no opening for appeal against these decisions (per Art. 638 of the WV).

The claim cannot be brought by the company or by a subsidiary of it. This remedy is often exercised in cases wherein a company has reached deadlock where it is not possible per se to 'blame either side' (or where, on the contrary, it could not be argued that both sides can be blamed in the same way).

In Belgian case law, valid reason exists when, for example, a significant threat to the interests of the company or its sustainability is present and in situations that fall under the British Unfair Prejudice Rule 48

45 Schweizerisches Zivilgesetzbuch (Fünfter Teil: Obligationenrecht) vom 30. März 1911 (in effect from 1 February 2021) <www.fedlex.admin.ch/eli/cc/27/317_321_377/de> accessed 2 July 2021.

46 Wedemann (n 1) 573

47 Wetboek van vennootschappen. Opgeheven door W 2019-03-23/06, art 34, 084; Inwerkingtreding : 01-05-2019 en uiterlijk op 01-01-2020; zie overgangsbepaling: art 38 tot 44 (2019) <www.ejustice.just.fgov.be/cgi_loi/change_lg_2.pl?language= $\mathrm{nl} \& \mathrm{~nm}=1999 \mathrm{~A} 09646 \& \mathrm{la}=\mathrm{N}>$ accessed 2 July 2021.

48 This remedy was already in place in the law of the UK as far back as in 1948, and before the corporate-law reform of 2006 it was regulated by arts 459-561 of the Companies Act. The Companies Act in effect since 2006 (available at <www.legislation. gov.uk/ukpga/2006/46/contents >) also provides for such a remedy; namely, art 994 foresees that a shareholder may apply to the court on grounds that the company's affairs are being, or have been, conducted in a manner that is unfairly prejudicial to the interests of members generally or such that an actual or proposed act or omission by the company is, or would be, so prejudicial. The shareholders whose rights are affected may represent all or only some of the shareholders, but the condition that must be met if they are to bring charges is that at least the rights of the petitioner have been violated. This remedy is considered to be complex and flexible because the court has the right to assess various aspects of the company's business 
(e.g. cases of abuse caused by the majority at the expense of a minority or situations wherein a minority maliciously blocks decisions necessary for the activities of the company). Any material breach of the obligations of the shareholder may constitute valid reason. Such infringement might occur, for instance, in a situation wherein the shareholder has not honoured the commitment to participate in the increase of capital or in a situation in which the shareholder is expected to be active but instead shows complete passivity with regard to the company's affairs. Significant personal disputes between shareholders (which may be connected with, for example, a divorce) also constitute valid reasons. ${ }^{*} 49$

The price at which a share must be disposed of has to be fair. It is determined by the court, usually relying on an expert. The case law demonstrates the use of several distinct methods to determine the price. Often, the DCF method ${ }^{*} 50$ is used, but sometimes the value of the share is determined on the basis of accounting value instead. It is also common for the court to ask an expert to calculate the value by using several methods and then calculate the value as an average of the figures produced. ${ }^{*}{ }^{51}$

Under Belgian law, the principle 'all or nothing' applies. That is, once a shareholder has initiated the proceeding, he or she cannot end it on the grounds that he or she does not agree with the compensation specified; neither is it possible to transfer his or her share after the initiation of proceedings. ${ }^{*}{ }^{2}$

\subsection{The Netherlands}

In the Dutch Civil Code ${ }^{*} 33$, the exit options for a shareholder of a closed company are regulated in articles 2:336-2:343. ${ }^{*} 44$ Where Belgium's provisions governing exit rights are relatively compact and clear, Dutch law is more complicated.

According to Dutch law, one or more shareholders, who solely or jointly have provided at least one third of the issued share capital, may make a claim in court from another shareholder who, through his conduct, is harming or has harmed the interests of the company in such a way that continuation of his share ownership cannot reasonably be tolerated any longer, such that he or she is to transfer his or her shares to the plaintiff(s) (see articles 2.336 and 2.341 of the BW). Article 2:336(2) of the BW, similarly to Belgian law, foresees that the claim may not be presented by the company itself or a subsidiary of it. If the aggrieved shareholder is an investment firm that only holds the shares, it can present the above-mentioned claim only if the actual shareholders agree. ${ }^{*} 55$

Article 2:337(1) of the BW must also be regarded as an essential provision, according to which, if the articles of association or a shareholders' agreement features an arrangement for resolving such disputes, it is not possible to appeal to that arrangement in derogation from the law to the extent that it makes the transfer of shares impossible or extremely difficult. According to Article 2:338(1) of the BW, the defendant may not, during the court procedure, ${ }^{*}{ }^{6}$ dispose of or encumber his or her shares without the plaintiff's consent. However, if the plaintiff refuses to consent to this action, the court may, at the defendant's request, give that consent if the defendant has a reasonable legitimate interest in it.

operations and simultaneously resolve different types of conflict. See further details provided by M Vutt, Systematics of Shareholder Remedies - Origins and Developments (2010) XVII Juridica International 194.

49 A Bertrand and A Coibion, 'Shareholder Suits against the Directors of a Company, against Other Shareholders and against the Company Itself under Belgian Law' (2009) 6(2-3) European Company and Financial Law Review 270, 295-96. - DOI: https://doi.org/10.1515/ecfr.2009.270.

50 The discounted cash flow method is used also to calculate the compensation paid to minority shareholders in the event of take-over, and it has also been considered appropriate in Estonian case law. See Supreme Court Civil Chamber Decision 3-2-1-145-04, para 34.

51 Bertrand and Coibion (n 49) 297.

52 See H de Wulf, 'Exit Rights and Forced Exits in Belgium' (presentation at the conference Commercial Code 20: Experiences and Development Opportunities of Estonian and European Company Law, Tartu, 22-23 October 2015) <www.oi.ut.ee/ sites/default/files/oi/hans_de_wulf.pptx> accessed 2 July 2021.

53 'Dutch Civil Code (Civil Code of the Netherlands)' (English translation) <www.dutchcivillaw.com/civilcodegeneral.htm> accessed 2 July 2021 (BW).

54 The relevant rules are situated in the part of the BW that regulates the rules for resolving disputes between shareholders.

55 According to art 2:336(3), the District Court of the domicile of the company has exclusive jurisdiction in the first instance over the right of action. An appeal against its decision may be lodged only with the Enterprise Chamber (ondernemingskamer) of the Amsterdam Court of Appeal.

56 Meaning from the moment of the defendant having received the case materials until the entry into force of the court decision. 
Under Dutch law, experts shall be involved in the procedure. Article 2:339(1) of the BW provides that the court is to appoint one or more experts responsible for drawing up a written opinion on the value of the shares in question. Where an arrangement related to the assessment of the value of shares applies between parties on the basis of the articles of association or the shareholders' agreement, the experts shall make their report with due observance of that arrangement. If, however, the rules foreseen in the articles of association or in the contract would lead to a manifestly unfair result in the effort to determine the fair value, the court may disregard it (per Art. 2:340(3) of the BW).

Article 2:341(1) of the BW sets forth the rules on alienation of the shares, and according to those regulations the plaintiff must transfer his or her share within two weeks from the date on which the final decision has been served to the defendant. Similarly, the applicant is obliged to pay a fixed value (price) for the shares at the time of receiving them. If other shareholders have joined the original claimant in the proceedings, they are entitled to the same right as the applicant. The transfer of the holding is to be in line with the initial proportion of the holding to the maximum extent possible (Art. 2:195 of the BW).

Article 2:343 of the BW regulates the reverse procedure, the withdrawal. A shareholder who has been somehow damaged by the actions of other shareholders in such a way that he or she cannot reasonably be expected to continue to participate in the company may bring an action against the other shareholders for exiting the company while demanding that the other shareholders acquire his or her shares. In certain circumstances, it is possible to bring such an action against the association also, but the rules foreseen for the acquisition of a company's own shares must be followed. In general, the withdrawal requirement is subject to the same principles as an exclusion application. The terms for a special procedural measure stipulated in Article 2:343(3) of the BW provide that, where a claim is brought against a shareholder, the latter shareholder may summon another shareholder or the company if he or she holds that such a claim should have been brought against them. Article 2:343(4) provides that, where a court determines the value of a share, it may, at the applicant's request, increase the price to a reasonable extent if a reduction in the value determined was linked to the actions of the defendant or someone else and the court concludes that the impairment should not be entirely borne by the claimant.

\subsection{Summary of the experience of other countries}

It is apparent from the above that countries with a private law system similar to Estonia have approached shareholder exit differently. In Germany, it is possible to apply to the court for the dissolution of the company. At the same time, German case law affirms the shareholder's right to leave the company for good reason or to exclude a shareholder from the company for good reason. This is justified by the fact that every party to a long-term legal relationship must be able to terminate that relationship if there is valid reason. In Switzerland too, there are rules on the dissolution of the company but, in addition to that, the right of exclusion and that of withdrawal are regulated. It has been noted, however, that the latter rules have not been fully implemented in practice. In the Netherlands, there is a complex and not very well-functioning set of rules on shareholder exit, while, finally, Belgium, on the other hand, has relatively simple and functional legislation in this domain.

One can conclude, therefore, that, though the solutions may be different, all of the European countries considered have, at least to some extent, established shareholder exit regulations.

\section{Proposals of the working group for amendment to Estonian company law}

As a result of Estonian company law revision, the working group proposed repeal of the provision currently regulating a shareholder's exclusion and inclusion of new exit rules in the law, which would provide new, clear provisions for shareholder exit. The proposal covers both the shareholder's right to withdraw from the company for good reason and the possibility of applying for the exclusion of some shareholders from the company when good reason exists. ${ }^{*} 7$ In October 2019, the working group for revision of Estonian company

‘Ühinguõiguse revisjoni analüüs-kontseptsioon’ (n 6) 742. 
law presented a draft law for amending the Commercial Code. This comprises regulations addressing all of the above-mentioned subjects. ${ }^{*} 8$

Under the proposed amendments, a shareholder may be excluded if there is valid reason for exclusion, which may be, in particular, activities by that shareholder that significantly jeopardise the achievement of the company's objective and the existence of other circumstances that, in light of all the circumstances and mutual interests, render it impossible to reasonably expect the private limited company to tolerate the future 'membership' of the shareholder in question. The draft also provides an illustrative list of circumstances that justify the exclusion of a shareholder. For instance, a shareholder may be excluded if he or she causes significant damage to the interests of the company. Said damage should, at least in general, be long-term and systematic if it is to qualify. Long-standing and insurmountable disagreements between shareholders that hamper the company's activities may form another valid reason.

The shareholder cannot be excluded, however, if the negative consequences that threaten the company could be overcome through other reasonable measures. What remedies are reasonable in a particular case depends on the situation and, in the event of a dispute, is to be decided by the court. In this setting, a shareholder who opposes the exclusion can demonstrate that there exist such reasonable measures as rule out the right of exclusion.

Shareholders holding at least $50 \%$ of the votes associated with the shares has the right to apply to the court for the exclusion of another shareholder. Therefore, an exclusion application can be submitted in cases of a company experiencing deadlock. A minority shareholder, on the other hand, cannot claim the exclusion of a majority shareholder, and $50 \%$ of the shareholding giving the right to submit an application takes into account all the votes in the company. ${ }^{*} 59$

If the court excludes the shareholder, the decision must include the statement that the shareholder shall be deemed excluded once he or she receives compensation in the amount determined by the court in the same procedure. So long as this compensation has not been paid to the shareholder, the shareholder retains all shareholder's rights. If the compensation cannot be paid because its payment would be against the rules on the preservation of equity capital, the shareholder cannot be excluded; however, the shareholder(s) who initiated the exclusion procedure can apply to the court in this case for the dissolution of the company.

If there is a dispute as to the amount of compensation, it is to be determined by the court in the same court procedure. The compensation must be fair, since, in essence, the exclusion of a shareholder constitutes expropriation as that shareholder loses his or her ownership. The draft law provides that the compensation must, as a rule, correspond to the value of the share at the time the court order on the shareholder's exclusion is issued.

However, since the majority, by virtue of their controlling position, have an opportunity to reduce the compensation to be paid to the shareholder by decreasing the value of the share before court proceedings even begin (during their planning) and can continue to reduce it during the trial, the court is given the right to consider a time frame other than the time of the decision when determining the amount that constitutes fair compensation. When determining the amount of the fair compensation, the court may calculate it using any method of assessment that, under the circumstances, is the fairest. The principle is that the compensation must guarantee the excluded shareholder full economic compensation for the loss of his or her share and for the intervention in ownership.

The draft law also foresees the requirement to maintain equity capital. This means that, when paying compensation to a shareholder, the private limited company must comply with the requirements for the preservation of equity capital laid down by law. ${ }^{*} 0$ Ultimately, the equity-retention rule means that it may not always be possible to exclude a shareholder in the event of material assumptions being fulfilled. If compensation cannot be paid because its payment would bring the company into conflict with the requirements for the preservation of equity capital, the shareholder(s) who submitted the application for exclusion have the right to file an application in non-contentious proceedings and demand the dissolution of the company.

58 'Ühinguõiguse revisjoni töörühma eelnõu' ['Draft Law of the Commercial Code Amendment Act'] (13.1.2020) <www.just. ee/sites/www.just.ee/files/ariseadustiku_ja_teiste_seaduste_muutmise_seadus.pdf> accessed 2 July 2021.

59 One of the reasons the majority shareholder cannot be excluded is that doing so would probably contradict the obligation to maintain equity capital.

60 According to the specification of requirements for the maintenance of equity capital (s 171(2) ((1)) of the CC), the net assets of the private limited company (total assets minus total obligations shown under liabilities on the balance sheet) are not allowed to be less than one half of the share capital or less than the amount of share capital specified in s 136 of the CC. 
The draft law foresees rules for the withdrawal of a shareholder too, in circumstances in which there is valid cause. The right to withdraw is a minority right. A majority shareholder cannot withdraw from a company (because doing so in a manner compliant with the equity-retention requirements would be impossible), and also he or she seldom is interested in leaving a company he or she already has control over. To withdraw, the shareholder must submit a declaration of intention to the management board of the company. If the company does not object, it is not necessary to apply to the courts. If, however, the company considers the conditions for withdrawal not to be met, the company has the right to request court establishment of the nullity of the withdrawal.

A shareholder has the right to withdraw from a private limited company only if valid reason for doing so exists and, therefore, given all the circumstances and mutual interests, he or she cannot reasonably be expected to stay in the company. Valid reason exists, for example, in case the company has taken measures that, from the position of the withdrawing shareholder, result in a change in legal or economic relations within the company to an unreasonable extent. A valid reason can be any substantial restructuring that significantly infringes the rights of the shareholder wishing to withdraw. There may be valid reason also in a situation in which the majority has maliciously and purposefully (i.e. without real need) started to increase the share capital to a significant extent, thereby expressing a desire to 'dilute' the aggrieved shareholder's participation such that it becomes so marginal that he or she can no longer exercise even the most basic minority rights. In contrast, a valid reason would not exist when, for example, the shareholder wishes to sell his or her share but is unable to do so or if the shareholder has a claim against the company arising from contractual relations between the shareholder and the company. A shareholder shall not be entitled to withdraw if he or she can sell his or her shares at a fair price and thus leave the company.

Another vital condition is that the withdrawing shareholder must receive fair compensation for his or her share. The amount of compensation due shall be pinned to the time of withdrawal. If there is no dispute between the parties, the leaving shareholder does not need to go to court. If, on the other hand, the private limited company does not agree to the payment of compensation or to the amount determined for it, the shareholder may exercise a right to apply to the court and demand the compensation be determined and paid. The court has the right to take into account timing other than the time of submission of the application for withdrawal when determining what constitutes fair compensation - for example, it might do so in a situation wherein the economic situation of the private limited company has deteriorated significantly in the meantime because of objective factors beyond the control of the majority.

The exclusion of a shareholder must simultaneously comply with the requirement to maintain equity capital. Hence, even if there is a valid reason for withdrawal, the shareholder cannot withdraw if the payment of compensation would fall foul of the equity capital rules. In this case, the shareholder wishing to withdraw has the right to apply for the dissolution of the company.

In addition, the draft law enables the shareholders to introduce rules on exclusion or withdrawal in the articles of association that differ from rules provided by law. ${ }^{*} 1$

Finally, the draft law is designed to introduce the possibility of applying for the dissolution of the company in case grounds for the exclusion or withdrawal of a shareholder exist when it is not possible to comply with the requirements for the maintenance of equity capital. Accordingly, the dissolution of a private limited company is possible but only if the material assumptions made in relation to exclusion or withdrawal hold true. If the court has established that there is no valid reason for the exclusion or withdrawal of the shareholder, it is not possible to terminate the private limited company. Under the proposed amendments, the right to apply for dissolution cannot be excluded or modified via the articles of association.

61 However, the requirements set forth for maintaining the equity capital are mandatory; that is, the articles of association shall not provide that a shareholder may be excluded or that the shareholder may withdraw even if the payment of the associated compensation would contradict the rules for preserving the equity capital. 


\section{Conclusions and future developments}

During the review, the working group were in no disagreement as to whether such rules would be necessary in future Estonian law. Current law neither provides sensible solutions for resolving conflicts between the majority and the minority shareholders nor includes remedies for a company in deadlock. This situation cannot be considered acceptable in contemporary company law. Experience shows that the existing remedies are clearly insufficient. Being embroiled in various legal disputes only creates a burden on the company and thereby reduces the value of its shares or, in the worst case, leads to the dissolution or even bankruptcy of the company. Of course, shareholder exit rules are not a miracle cure for all possible problems, as this remedy is suitable only for companies in a relatively good economic situation that are able to pay compensation to the exiting shareholder. Every exit is accompanied by costs that burden the company to some extent. At the same time, practice shows that when shareholders attempt to resolve a conflict via other legal remedies, most actions are simply ones of protest that encumber the company even further.

Analysis of the law of other countries shows that the necessary rules in themselves can be laid down by law. Although there are currently theoretical possibilities for the exclusion and withdrawal of shareholders in Estonia, they have not been actualised in case law. Legal clarity is a value in its own, and in order to reach this objective, it is justified to introduce appropriate rules.

When drafting the proposals, the working group did not use the law of any particular country as a model. The proposed rules are combinations that synthesise the relevant regulations of several countries, considering, among other factors, the principles of Estonian law of obligations and civil procedure. The courts have been given an extensive right to substantiate the validity of the reasons for the exclusion and withdrawal of a shareholder, considering the circumstances of the particular case. In this respect, the proposed approach does not differ from the law of other countries, since it is not possible to resolve cases of this kind without discretion of the court.

The authors of this article admit that introducing the proposed rules probably necessitates specialist judges who are able to assess whether there is a valid reason for the exclusion or withdrawal of a shareholder in a particular case, along with whether the private limited company would remain in compliance with the law's requirements for the maintenance of equity capital after payment of the requisite compensation to the departing shareholders. However, the authors are of the opinion that the proposed solutions should help to bring at least some ongoing disputes between shareholders to an end and, thereby, avoid the dissolution or insolvency of the relevant private limited company in these cases.

At the time of writing, no official draft law has been submitted yet, so it is not known whether the proposals for amendments will be adopted. But the authors are of the opinion that legal regulation of shareholder exit is a fundamental necessity for improvement of Estonian company law. 